\title{
17 Economy, Frontiers, and the Silk Road in Western Historiographies of Graeco- Roman Antiquity
}

\section{The Mediterranean and Trans-imperial Exchange}

Although the last few years have seen a surge of publications on Indo-Roman trade and Silk Road exchange, ${ }^{1}$ the trans-imperial trade connections of the Hellenistic and Roman Empires have never been central to the field of Graeco-Roman history. The Greeks and Romans were Mediterranean societies. Their involvement in Asia beyond Asia Minor was the result of colonization, annexation, and conquest, but not central to their cultural formation, empire building, and economy. ${ }^{2}$ The Mediterranean perspective of studies on Greek and Roman culture, that explains itself by the origin of Graeco-Roman history in Greek and Latin philology, gained further momentum by a new interest in Mediterranean connectivity that developed in the wake of the English translation of Fernand Braudel's La Méditerranée et le monde méditerranéen à l'époque de Philippe II (1949) in 1972. Since then, Graeco-Roman culture and economy could be even more convincingly, and more comprehensively, located in the Mediterranean Basin. ${ }^{3}$ The subject of ancient history was no longer defined just by the languages, but instead by geographical, cultural, and economic cohesion of the ancient Mediterranean. In 2000, Horden and Purcell published a volume full of knowledge and insight about ecologies, microclimates, nutrition, settlement patterns, and systems of travel and exchange that gave life to the Mediterranean as a connected human landscape. In an often-quoted phrase, they summarized the Mediterranean's most important characteristics as fragmentation and connectivity: "We have identified extreme topographical fragmentation as one of two environment ingredients - along with the connectivity provided by the sea itself - in a distinctly Mediterranean history." 4

The unity of the Mediterranean is a construct, but it has some natural basis: The region was the home of particular vines, the European olive, and certain types of wheat typically consumed by Greeks and Romans; it was a unified climatic zone and it was relatively easily navigable. The very uneven distribution of natural re-

1 Matthew 2015; de Romanis and Maiuro 2015; McLaughlin 2016; Evers 2017; Wilson and Bowman 2018 (part III); Cobb 2018; 2019.

2 See, however, Fitzpatrick 2011 with a different emphasis. For the Mediterranean orientation of the Hellenistic Empires, see von Reden, ch. 1, this volume.

3 See, however, Burkert (1984) 1992; Morris and Manning 2005, 17 for further dissenting voices.

4 Horden and Purcell 2000, 175.

Ә Open Access. (c) 2020 Sitta von Reden and Michael Speidel, published by De Gruyter. (cc) BY-NC-ND This work is licensed under the Creative Commons Attribution-NonCommercial-NoDerivatives 4.0 License.

https://doi.org/10.1515/9783110607741-026 
sources, especially metals, and its diverse microclimatology encouraged a system of Mediterranean-wide trade. ${ }^{5}$ Yet the Mediterranean is also a political instrument. In an important colloquium four years after the publication of Corrupting Sea, Herzfeld called the Mediterranean a civilizational ideal, a "strategy of self-stereotyping," and part of the "politics of humiliation" in a global national hierarchy. ${ }^{6}$ Bagnall in the same colloquium emphasized the ambivalent place of Graeco-Roman Egypt in this socio-geographical scheme. Despite Egypt's extended Mediterranean coast, he argued, it never fully belonged to the category of a Mediterranean society, nor Graeco-Roman Egypt to the realm of ancient history proper. ${ }^{7}$

Greeks and Romans themselves anchored their cultural belonging in the Mediterranean Sea. Contacts and exchange between Asia and Egypt had been intense from the times of the Bronze Age onward - not least mediated by Greek settlement on the Ionian and Levantine coasts, the Egyptian delta, and Cyprus. ${ }^{8}$ But it was in the aftermath of the Persian Wars that a strong sense developed (forced to emphasize unity) that Greeks lived as free citizens in city-states in a manner that came to be seen as typical of Greece and the Aegean Sea, while Persians were by nature subjects. ${ }^{9}$ In this self-imagination, barbarians neither participated in, nor were affected by, the more advanced culture of poleis. Geographical and medical writers placed Greek civilization in the world's temperate central zones, while people either more savage or softer, but in any case less civilized, inhabited the climatically more extreme regions toward the edges of the world. ${ }^{10}$ As the Macedonians conquered Asia and Egypt, kings and immigrants were drawn to the Mediterranean coast lines: Alexandria in Egypt was founded on the Mediterranean, and soon replaced Memphis as the royal capital; the Seleukids shifted their political core from the Persis to Babylonia and connected it via roads and colonial foundations to the newly built capitals Antiocheia and Seleukeia on the Syrian coast. ${ }^{11}$ Even long after the expansion of the Roman Empire, Rome never ceased to be the uncontested center of the Roman Empire. It was not only the seat of the emperor, but also the center of the orbis terrarum that could be grasped conceptually and geographically only from a central and elevated vantage point. ${ }^{12}$ A monument called the Golden Milestone (milliarium aureum) erected by Augustus in 20 BCE in the center of the city symbolized Rome's central position in its world: all roads led here.

5 Harris 2005, 5-6.

6 Herzfeld 2005, 48, 52, 59; also Morris and Manning 2005, 19-22 for the politics of the Mediterranean paradigm.

7 Bagnall 2005.

8 Most recently Broodbank 2013 on these connections and their role in the formation of Mediterranean unity.

9 Cartledge 1993, 36-63.

10 See von Reden, ch. 8 B, this volume.

11 See von Reden, ch. 1, this volume.

12 Murphy 2004, 129-164. 
Economic history and theory furthered Mediterranean unity. In a famous passage introducing his influential The Ancient Economy (1973), Moses Finley defended a unitary perspective on the Graeco-Roman economy with reference to its difference from those of the ancient Near East, the Babylonians, Phoenicians, Egyptians and Persians:

The Near Eastern economies were dominated by large palace or temple complexes, who owned the greater part of the arable virtually monopolized anything that can be called 'industrial production' as well as foreign trade ... and organized the economic, military, political and religious life of the society through a single complicated, bureaucratic, record-keeping operation for which the word 'rationing,' taken very broadly, is a good one-word description. None of this is relevant to the Greco-Roman world until the conquests of Alexander the Great and later the Romans incorporated large Near Eastern territories. At that point we shall have to look more closely at this Near Eastern kind of society. ${ }^{13}$

He left the issue at that point, since, as he argued, if he were to define 'ancient' to embrace both worlds, there was not a single topic that could be discussed "without resorting to disconnected sections, employing different concepts and models." Finley conceded that there were forms of private landownership and labor also in the Near East, and there were also independent craftsmen and traders in the towns. Yet it was not possible to elevate these people to driving forces in the economic development of the Near East, whereas the Graeco-Roman economy was essentially one of private property. ${ }^{14}$

While Finley did not discuss the factors that changed the Near Eastern and Egyptian economies after the Macedonian conquest, the editors of the more recent Cambridge Economic History of the Greco-Roman World (CEHGRW) emphasized the justification of Graeco-Roman unity in a broader sense. The division between east and west in antiquity was overstated, but there were very real differences between "most of the economic systems of Egypt and the Near East, in which temples, palaces and redistributive bureaucracies performed crucial functions, and those of the Greeks and Roman societies, where they generally did not". ${ }^{15}$ However, the category of Graeco-Roman economy was dislocated from its Mediterranean home, insofar as Greek and Roman institutions and practices were exported to other regions. ${ }^{16}$ Both before the Classical period (479-336 BCE) but especially after it, there were many connections and interpenetrations of these essentially different systems. Accounts of the pre-Hellenistic Near East, Seleukid Asia, Ptolemaic and Roman Egypt as well as the Roman frontier zones were naturally included in the CEHGRW. They demonstrated the gradual transformation, continuity, and change under Graeco-Roman presence. No uniform picture emerged from these regional views. However, and

13 Finley (1973) 1985, 28.

14 See Baker and Jursa 2014; Jursa 2014.

15 Morris, Saller, and Scheidel. 2007, 8.

16 Bingen (1978) 2007. 
simplification permitted, the conclusion of most chapters was that the impact of Graeco-Roman institutions, private property rights, monetization, technological knowledge, and the logistics of transport and trade led to an increase in market exchange and economic performance. ${ }^{17}$ Some authors were hesitant to attribute increased performance just to Graeco-Roman institutional change: Monetization and monetary tribute of the Near East began in the age of Dareios; experimentation with new, more marketable agrarian produce built on pre-Hellenistic trends in Egypt; and army presence in Roman frontier zones had very different kinds of impact in different provinces. ${ }^{18}$ Yet it was Graeco-Roman presence and their institutions and forms of knowledge that led to new economic practices and levels of performance.

In a thought-provoking study, suggestively entitled The Roman Bazaar (2008), Bang criticized this approach to the Graeco-Roman economy. Its overly Western outlook, which centralized markets, private property, and individuals as driving forces of economic development, in fact projected dynamics that had in fact emerged much later in the context of the European nation state into the imperial world of antiquity. The economic development of tributary empires had a different logic. To ignore this put one in danger of reinforcing European orientalism, which belittled the prosperity of Asian empires before European colonialism. ${ }^{19}$ The market model, characterized by monetary exchange, private property rights, and rational choice, was deeply impregnated by the universalist claims of classical political economy that developed in Early Modern Europe. Competition between independent nationstates and governments, international opportunities for competitive investment of commercial capital, and mercantilist politics were typical for this historically unique state system. The Roman Empire, in contrast, was not part of a competitive state system, nor were its provinces autonomous states. It resembled rather more the early modern tributary empires of Asia, the Ottomans, the Mughals, or China of the Ming and Ch'ing dynasty. Inter-state competition was a much weaker dynamic in these, and also in the Roman Empire. "The Roman state was already the most powerful and had much less in need to privilege commercial groups; it could concentrate on taxing its vast population, particularly the peasant masses."20

The authors of the Cambridge Economic History of the Greco-Roman World approached the ancient economy from its centers. The main subjects of inquiry were the city-states of Greece and Italy where the development of free peasantries, private property rights, and monetization had played an undeniably positive role for economic performance before the Hellenistic period. The impact of the imperial expansion of the Greek world from the late fourth century BCE, and of the Roman world from the late third century BCE, continued to be viewed (as in Graeco-Roman history

17 Shown more thoroughly for Roman Egypt by Monson 2012.

18 Van der Spek 2007; Manning 2007; Cherry 2007.

19 Bang 2008; Morris 2010 for a long-term analysis.

20 Bang 2008, 12. 
more generally) from the perspective of the old and new Greek and Roman centers. The Hellenistic capitals and later the city of Rome profitted from the economic development of the conquered land, and in turn these regions developped under the influence of the Greeks and Romans. Contacts beyond the Graeco-Roman Empires, moreover, played a relatively subordinate role. In a chapter discussing the Seleukid economy of the third to first centuries BCE, van der Spek, for example, raised the question of whether trade with Central Asia increased in the Seleukid Near East, but found no positive evidence. ${ }^{21}$ Rathbone, writing on Roman Egypt (first to third centuries CE), was well acquainted with the spectacular value of trade between Egypt and India in the first century CE. Nevertheless, he saw the impact of this trade to be limited to a small elite of financiers in Italy and Alexandria, and the manufacturing industries in Alexandria and Koptos where the import of perfumes, textiles and spices generated processing industries. ${ }^{22}$ Imports from Arabia and India, and their visible traces in Palmyra and the ports of the Red Sea coast, receive due attention in Morley's and Alcock's accounts of trade in the Roman Empire and the Eastern Mediterranean respectively. But once again, they are described as separate phenomena. Although profoundly affecting Palmyra as a nodal city on the routes to the Gulf and further on, Roman imports served the consumption and financial interests of just a small Italian and Roman elite. ${ }^{23}$ Lo Cascio emphasized the low state rate of the Roman fiscal economy, while not discussing the potentially huge fiscal income from external trade and frontier zone development. ${ }^{24}$ In the dominant models of the Graeco-Roman economy, trade and exchange with India, Central Asia and further east were no more than comparable to the modern drug trade: highly profitable for some, and stimulating complex exchange networks, but with little impact on economy and society as a whole. The focus on the economic principles of the imperial cores, and the resultant lack of integrating peripheral zones into research on the economies of the Hellenistic and Roman Empires, made it difficult to even raise the question of their impact.

For a long time, research on long-distance trade with India, the Arabian Peninsula, Central Asia and beyond was the concern of academic subgroups, particularly archaeologists and papyrologists whose interest in Egypt, Arabia, and India led them to transcend mainstream ancient history. ${ }^{25}$ In 1954, Mortimer Wheeler published what then was regarded an authoritative study of Roman trade beyond its frontiers. ${ }^{26}$ Wheeler had been Director General of the Archaeological Survey of India

21 Van der Spek 2007, 423.

22 Rathbone 2007, 711.

23 Morley 2007a, 583-584; Alcock 2007, 689-690, both marking it as an aside of Roman trade.

24 Lo Cascio 2007; Bowman and Wilson 2018 for a different assessment of the fiscal income derived from cross-border trade.

25 Pioniering studies were Rawlinson 1916, Charlesworth 1924, and Warmington 1928, but their interest in trade was limited; see Evers 2017, 4.

26 Wheeler 1954. 
between 1944 and 1948, and after partition functioned as archaeological advisor to the newly formed government in Pakistan. In his Presidential Address to the Oxford meeting of the British Association in September 1954 entitled "Colonial Archaeology," he stressed that the theme of his lecture related to the safeguarding of cultural, historical, and archaeological heritage in Britain's colonial territories. ${ }^{27}$ More than 20 years later, Raschke, an ancient historian and Harvard-trained economist, was commissioned to write a chapter for the multivolume Aufstieg und Niedergang der römsichen Welt (1978). Raschke was eager to emphasize that there was no coordinated trade between Rome and the East. The silk trade was indirect, a series of uncoordinated exchanges starting with the Chinese tribute payments to the Xiongnu via enterprising merchants in Central Asia who sold their goods to Parthians and Indians until they reached the Roman borders in Syria and Egypt. ${ }^{28}$ This view that Eastern trade reached Rome at the end of a series of disconnected enterprises embedded in local exchange systems and consumption centers was adopted again 20 years later by Young. Archaeological projects in the Eastern Desert, the Red Sea ports and sites along the coast of the Arabian Peninsula have stimulated debate over the conditions of Indo-Roman trade, its development and decline, and the communities and people both involved in and driving it. ${ }^{29}$ Yet the crucial question of precisely how external contacts and exchanges affected local, and possibly also wider, systems of trade and exchange was not answered in any systematic or analytical way. Textual and archaeological research in combination suggest a complicated assemblage of local and long-distance exchange networks peopled by different communities and economic agents from all regions involved. ${ }^{30}$

The idea of a 'Silk Road' was adopted by the geographer and geologist Ferdinand von Richthofen (1833-1904) and came to symbolize the vitality of trans-Eurasian trade long before the modern period. ${ }^{31}$ Yet, both the term and the idea behind it have been met with much skepticism among ancient historians. Its romantic allusion to camel trains and caravan cities has popular appeal, but little analytical power. Its underlying assumptions of traders linking supply and demand at either end of the long route is certainly mistaken, as Raschke, Young, and many others have shown. ${ }^{32}$ Most scholars have toned down the term by referring to a number of 'silk routes' in inverted commas and including into this category multiple pathways on the way as well as maritime trade routes between India and Egypt where silk played a subordinate role. Some scholars insist that, in contrast to the maritime trade routes, evidence for overland movement of goods from China through Central Asia

27 Ray 2008, 1; Tomber 2008, 13-14.

28 Raschke 1978, e.g., 605.

29 Proceedings of the Red Sea Project I-V; Tomber 2008; Sidebotham 2011; Sidebotham and GatesFoster 2019; Cuvigny 2003.

30 Tomber 2008; Thomas 2009; Sidebotham 2011; Evers 2017.

31 Galli 2017, 4; Brown 2018, 98-99; and von Richthofen 1877-1912.

32 Wiesehöfer, ch. 11, this volume; Graf 2018; Cobb 2018. 
and Mesopotamia before Late Antiquity (ca. 400-ca. 650 CE) was scant, fragmentary, incoherent, and did not add up to a continuous well-frequented route from China to the Mediterranean coast. ${ }^{33}$

Both as a consequence of growing interests in global contexts and fruitful controversies over the Mediterranean character of the Graeco-Roman economy, the insularity of research on trans-imperial exchange is gradually dissolving. Thus, Evers asked in his 2017 publication:

What if the Mediterranean is better perceived of, at least for the purpose of some studies, not as a unit, but as part of a greater whole, such as the Eurasian landmass, or, as in this study, the periphery of the Indian Ocean? In this case, we need to think about the historiographical consequences of shifting Rome from being the center, to being $a$ center in the peripheral west of Eurasia, which is really just a late consequence of old and new discussions about the implications of postcolonialism and globalization for our interpretation of the Roman Empire ... [T]he old ways of writing about Indo-Roman trade die hard, infusing studies with a 'Romanocentric' bias as regards the sources singled out for analysis, in turn emphasizing Roman carriers of the trade and a Roman chronology for trade in the Indian Ocean. ${ }^{34}$

Less globally oriented, but equally forceful, Bowman and Wilson in their latest volume of the Oxford Roman Economy Project (OxRep) have called for a better integration of external trade into the Roman trade system:

It is our contention, in fact, that external trade, with the east whether via Palmyra and the Silk Road(s) or with the Arabian peninsula and India, and with (and even across) the Sahara, should be considered not merely as an exotic sideshow, but as a fundamental part of the Roman trade system from the reign of Augustus onward, important not only for the quantities of exotic imports that it introduced, but also for the fiscal revenue that the 25 per cent customs dues yielded..$^{35}$

The two statements address very different problems. Evers asks us to rethink the position of the Roman Empire in a global post-imperial world, in which the Romans no longer were the central players. He questions the role of Rome as the initiator of global interaction, its rhythms and directions, as well as the autonomy of the Roman Empire in a multi-imperial orbit. He also qualifies, if not yet explicitly, the centrality of the city of Rome in a 'hublike' imperial structure within which the center dominated its peripheral regions to channel resources to the core. ${ }^{36}$ Addressing the social and economic organization of Indo-Roman trade in which more than

33 Millar 1998; Sartre 2000; Ball 2000; disputed by McLaughlin 2014; 2016, and Graf 2018; for the latest assessment, Gregoratti 2019.

34 Evers 2017, 4 and 5; also Fitzpatrick 2011, and Ball 2007.

35 Bowman and Wilson 2018, 13; Wilson 2015.

36 Motyl 2001 for this model of imperial structure; Scheidel 2012, 27-28 for discussion. According to Hopkins 1995-1996, Morley 2007a, and Morris, Saller, and Scheidel 2007, the city of Rome as a consumption center was the single most important factor driving economic performance, trade and market development in the Roman Empire. 
one empire or polity was involved, Evers draws our attention to the multifaceted assemblage of regions, communities and frontier regions that were involved. These were not just middlemen and transit zones in Indo-Roman trade, but active participants in the construction of the system. Bowman and Wilson, by contrast, do not question the dominating role of the Roman Empire and the centrality of Rome in Indo-Roman trade. They emphasize the fiscal and financial interest the Roman state took in the income derived from this trade. But they urge us better to integrate external trade into our understanding of the ancient economy. They invite us to think more carefully about the role external trade played in the state budget, and in the complex connection between tax income, coin supply, and military expenditure. ${ }^{37}$

The two issues, though related, lead into different and unconnected traditions of ancient historical research. The one concerns the nature of the ancient economy, the other relates to the political construction of the Roman Empire and its relation to its frontiers. Both contribute to the issues at stake. In order to answer the questions raised in this handbook, we will need to bridge these two fields of study: What were the dynamics of the ancient economy, which sources of income were generated, and how did ancient governments engage in the development of the economy? To what extent did the Roman interest in its border zones extend beyond preparing for warfare, defending possessions, supplying troops and exploiting resources? How were economic frontiers integrated into the Roman Empire and its economy? Did the Roman state identify economic interests in connection with its frontiers, and which measures did it take to pursue and defend such interests?

Studies of both the ancient economy and of the Roman frontiers have generated an enormous amount of scholarship, of a highly detailed as well as conceptual kind, which can only be discussed in their broadest outlines here. Yet, although they are in many respects closely related, the traditions of research have little overlap. ${ }^{38}$ To a significant extent this was a consequence of very diverse historiographic developments, as these themes were pursued by two distinct groups of specialists without much direct scholarly exchange.

\section{Sitta von Reden}

\section{Trends in the Historiography of the Graeco-Roman Economy}

\section{II.1 The Ancient Economy and European Modernity}

Ancient economic history developed as a subject of academic research in connection with the emergence of European capitalism and the field of classical political

37 Bowman and Wilson 2018, 14.

38 Cf. e.g., Young 2001; Sidebotham 2011; Speidel 2016. 
economy within philosophical inquiry in the late eighteenth century. It was pioneered by the groundbreaking study Die Staatshaushaltung der Athener (1817) of the Berlin classical philologist August Boeckh, which was rapidly translated into English as The Public Economy of Athens (1827). Boeckh compiled all available literary and epigraphic data about prices, wages, interest rates, public income, and expenditure, and framed them with discussions of demography, agriculture, manufacture, commerce, money and credit, mining, slavery, nutrition, clothing, and total costs of living in Athens. He thereby defined a subject area for ancient economic history that was strongly influenced by the national economies emerging in Western Europe at the time and the theoretical reflection about them in Scottish moral philosophy. ${ }^{39}$ Well into the eighteenth century, economic theory had been shaped by the classical separation of agrarian household management (oikonomia) on the one hand, and commerce (Gk chrematistike, lat. commercium), on the other. ${ }^{40}$ It was only in the Scottish enlightenment, culminating in Adam Smith's An Inquiry into the Nature and Causes of the Wealth of Nations (1776) that there developed an integrated notion of political economy. It connected these fields and constituted the relationship between consumption, agrarian as well as commercial production, and market distribution as the joint foundations of national wealth. Smith, however, regarded his economic model, and its underlying principle of the profit-seeking individual, as typical not only for contemporary national economies, but as universally valid. This universal claim gave the study of economic history a teleological direction toward Western economic liberalism that has never vanished. ${ }^{41}$

However, the universalizing claims of economic theory immediately met with critical response. The maximizing principle of human behavior in particular was called into question. According to Adam Smith, individuals served the interests of others not out of a sense of benevolence or charity, but out of self-interest and calculation. ${ }^{42}$ The term homo oeconomicus, which still stands for the maximizing principle today, was coined by John Stuart Mill as a critical objection against the notion of the profit-seeking individual, as it so strongly contradicted the classical concept of mankind as homo politicus. Accordingly, the market of the invisible hand that Smith envisioned as not just a distribution mechanism but as the basic means of political integration, was questioned. The German Historical School of National Economics that developed around Wilhelm Roscher (1817-1894) responded to the universalistic model of the Scottish enightenment scholars by relating the economy of the present to a historical process of gradual emergence. In the subsequent generation of scholars around Gustav Schmoller (1847-1930), economic theories were de-

39 Schneider 1988.

40 Burkhardt, Oexle, and Spahn 1992.

41 Bang 2008; Morley 2009, 21-46.

42 Smith (1776) 1961, 26-27. 
veloped on the basis of empirical historical investigations, from which the preconditions of modern capitalism were derived.

Classical economics was developed further by the Neoclassical School. Influential economists such as Léon Walras (1834-1910) in France, Carl Menger (1840-1921) in Germany and Alfred Marshal (1842-1924) in Britain theorized the market as a price formation mechanism based on supply and demand (equilibrium). ${ }^{43}$ Constituting equilibrium as the principle goal of markets, and markets the center of economic analysis, they transformed economics into a science based on quantifiable data and mathematical models. The maximizing principle was developed further into the concept of rational choice according to which economic agents always strive to make decisions to their best advantage, and thus make choice available for marginal cost calculation. To this day, neoclassical economic theory forms the basis of mainstream economics. For the investigation of precapitalist and non-Western economies, however, there remain only two options. Either the principles of modern economic theory are assumed to be generally valid, or they are regarded as the outcome of modern capitalism and largely useless for understanding precapitalist economies.

Since these controversies, the question of what constitutes economic history has been central to Graeco-Roman economic historians. If economic history is defined as the study of markets whose price formation processes are to be examined, ${ }^{44}$ it is very difficult to gather appropriate data. As we shall see below, ancient historians nevertheless have attempted to do so. At the other end of the spectrum are anthropological and cultural approaches that have developed in opposition to the neoclassical paradigm. They define an economy most broadly as the sum of activities that secure material livelihoods. ${ }^{45}$ Relationships, social values, and local models of meaning are at the center of such approaches and have led to historical research that may be regarded as much as cultural as economic history. ${ }^{46}$ While cultural approaches to the Graeco-Roman economy were en vogue during the 1990s, and led to much collaboration between anthropologists, literary critics, and ancient historians, in the last 20 years the pendulum has swung back to economic history in the neoclassical sense. ${ }^{47}$ However, neoclassical approaches have become more accommodating to historians of premodern economies in the course of the debates over Neo-Institutional Economics (NIE). For NIE economists, rational choice, the calculating individual, and market development are still essential to the analysis of economic processes. However, the institutional (that is, normative and legal) contexts of markets and the normative conditions of rational choice are given greater

43 Roll 1956.

44 Roll 1956, 373.

45 Polanyi 1977, 230.

46 Carrier 2012, 4-7.

47 Morris 1994; Morris and Manning 2005. 
prominence. ${ }^{48}$ This has offered new opportunities for studying the variable institutional influences on markets and behavior in historical perspective. Douglass North (1920-2015), a Nobel Prize winning economist, was particularly influential in redefining economic history as the task of identifying institutional and organizational conditions that explain structure and performance of historical economies through time. ${ }^{49}$ This approach had a major impact on research into ancient economic history in the twenty-first century.

\section{II.2 The Bücher-Meyer Controversy and the Ancient Economy}

Given its close connection with the emergence of Western modernity, ancient economic history has been concerned with its own theoretical assumptions more intensively than any other branch of ancient history. Its role in shaping modern thought and the role of Europe in the global cultural scheme came to the fore in the controversy between the national economist of the Historical School Karl Bücher (18471937) and the ancient historian Eduard Meyer (1855-1930). ${ }^{50}$ Bücher developed a model of European history that established a development of stages from the "closed domestic economy" of antiquity via the "city economy" of the Middle Ages to the "national economy" of modern times. ${ }^{51}$ With this model he met sharp criticism from Meyer, who defended the modernity of the ancient economy in the neoclassical sense. In his response to Bücher, Meyer sketched a picture of the gradual development of the Greek economy from the eighth century BCE onward toward a capitalist market economy. Trade, commerce, money, and market-oriented production drove a dynamic economy in classical Athens that reached its climax with banks and high volumes of credit in the fifth and fourth centuries BCE. ${ }^{52}$ The landowning aristocracy was replaced by an aspiring industrial bourgeoisie by the late fifth century. In his five-volume Geschichte des Altertums (1884-1902) Meyer compared the seventh to fifth centuries BCE in Greece to the fourteenth to sixteenth centuries CE in Europe. His colleague Julius Beloch largely adopted this model in his three volumes of Griechische Geschichte (1893-1904).

The dispute between Bücher and Meyer, introduced into ancient history by Moses Finley as the 'primitivist-modernist debate,' was highly influential for research on the ancient economy up to the early 1990s. ${ }^{53}$ In fact, Bücher and Meyer were concerned with more than the question of whether the ancient economy was primitive or modern. Meyer placed trade and markets at the center of ancient eco-

48 North 1990; Frier and Kehoe 2007; Bresson (2007-2008) 2016.

49 North 1981, 3.

50 Finley 1979 for a collection of key texts in English translation.

51 Bücher 1893.

52 For a rival of ancient capitalism, Bresson 2014; critically Bang 2008, 45.

53 Andreau (1995) 2001; Cartledge 1998; Nafissi 2005. 
nomic performance in the sense of the classical and neoclassical economy; Bücher, on the other hand, understood the economy as a part of political and social community-building in the agrarian household, the city, and the nation state. ${ }^{54}$ His concern was about structures rather than economic performance.

The extent to which the controversy over the ancient economy was implicated in contemporary debates over national economic performance and the welfare state is shown by the work of the sociologist Max Weber (1864-1920). ${ }^{55}$ Engaging with the methodological and historical conflicts of the Bücher-Meyer controversy in a long handbook article Agrarverhältnisse des Altertums (translated into English 70 years later as Agrarian sociology of ancient civilizations), he constructed a threesector model with a natural economy in the rural sector, a surplus production sector based on slave labor on large Roman estates, and a commercial sector in the cities. ${ }^{56}$ Important methodological change occurred between the second and third editions of this article. Weber abandoned the historical approach to economic systems and presented instead a theory of ideal types which was to have a great influence on the social sciences of the twentieth century. The three-sector model gave way to a more conceptual approach in which household economy, the slave mode of production, and the economy of cities were just mental constructs ('ideal types') for heuristic analytical purposes. ${ }^{57}$ Weber's sociological study on the ancient world initially had little influence on ancient history in Germany. Then, Johannes Hasebroek, a student of Eduard Meyer's, took up Weber's and Bücher's project and emphasized the profound influence of state and city-state social structures on ancient economies. One of Hasebroek's central ideas in his Staat und Handel im Alten Griechenland (1928) was that people without citizenship rights and landed property dominated trade and commerce. The outsider role of people involved in trade and commerce marginalized economic matters in politics, and thus prevented the emergence of a modern economy. Hasebroek's interest once again was concerned with economic structures rather than performance, and of emphasizing difference rather than similarity between ancient and modern economic behavior.

Yet it was Fritz Heichelheim (1901-1968) and the Russian émigré Michail Rostovtzeff (1870-1952) who dominated Western ancient economic history until the 1960s. They focused not so much on the Greek city-state, but rather on the development of interconnected markets and trade in the Hellenistic and Roman Empires. Heichelheim argued that the expansion of Greek culture in the Hellenistic period after the conquests of Alexander and the resulting demand for Greek luxury goods in Hellenistic royal courts and cities led to a massive increase in long-distance trade. This stimulated the creation of an economic area integrated by supply and demand from

54 Wagner-Hasel 2004.

55 Nafissi 2005; Eich 2006; Bang 2008.

56 Weber 1897.

57 Weber 1904 on the concept of ideal types. 
the Western Mediterranean to the Near East. ${ }^{58}$ It was no coincidence that one year after the Great Depression, Heichelheim published a study on economic cycles in the Hellenistic world on the basis of variations in wages, prices, and interest rates from Egypt, Delos, and Uruk. ${ }^{59}$ Less concerned with price data and economic scales, Rostovtzeff envisioned the Hellenistic and Roman Empires as dynamically moving toward a capitalist world economy. ${ }^{60}$ Against the background of his own experience of the modernization process of late imperial Russia, and a magisterial knowledge of ancient archaeological, epigraphical and papyrological evidence from Southern Russia, Syria, Egypt, and the Mediterranean, he designed a grand panorama of the Hellenistic and Roman economies driven by dynamic urban bourgeoisies, yet eventually held back by the primitiveness of the agrarian sector. ${ }^{61}$

\section{II.3 Polanyi, Substantivism and Finley's Ancient Economy}

The work of the Austro-Hungarian economist Karl Polanyi (1886-1966), who had emigrated in 1933 and lived in America from 1940, played a central role in anthropological discussions about alternative economic systems from the postwar period until the 1990 s and beyond. ${ }^{62}$ Shocked by the collapse of capitalism in the late 1920 s, he led an almost emotional campaign against the universal claims of liberal market economics. Instead, he developed an anthropological vision of market-less, simple or even socialist social formations prior to the triumphal advance of liberal markets. In precapitalist societies, economic behavior had been 'embedded' in social and political institutions. A self-interested homo oeconomicus that was free of social and ethical concerns of justice and fair exchange was an invention of capitalist society, as was an autonomous economic process that was socially "disembedded."63

Strongly influenced by leading anthropologists like Richard Thurnwald, Bronislaw Malinowski and Marcell Mauss, Polanyi developed an anthropological model of economic development that was based on modes of exchange and forms of social integration. These regulated the flow of goods in precapitalist societies: household exchange, 'reciprocity' (interpersonal mutual exchange based on ideas of fairness and justice), and state 'redistribution. ${ }^{64}$ Only in the course of the 'Great Transformation' during the early industrial age did market exchange develop into the fourth principle of integration (see Adam Smith, above). ${ }^{65}$ Polanyi later abandoned house-

\footnotetext{
58 Heichelheim 1938.

59 Heichelheim 1930.

60 Rostovtzeff 1939-1944; (1926) 1957.

61 Rostovtzeff (1926) 1957, esp. 538.

62 Humphreys 1978, 31-75; Nafissi 2005, 127-190.

63 Polanyi 1977.

64 Polanyi 1957b.

65 Polanyi 1944.
} 
hold exchange as an early form of social and economic integration. His model of economic development was also not a strictly evolutionary one. Thus there were forms of reciprocity and redistribution in capitalist societies, and market 'elements' could also develop in precapitalist societies. Moreover, in an influential article on the pseudo-Aristotelian Oikonomika, he argued that Aristotle had discovered political economy as a field of theory and planning independently of society and politics. ${ }^{66}$ Essential for the character of an economy was, instead, the question of which institutions were crucial for integrating a society or state. Moreover, market elements rarely if ever remained uncontrolled in preindustrial societies. He and his colleagues observed a certain type of commercial harbor in many contemporary African and historical societies, which he modelled into the concept of 'port-oftrade. ${ }^{67}$ These ports housed one or more trading communities, hedged in and protected by official or state control both for their own preservation and for the social protection of the local society. In contrast to the modern 'formalist' concept of the economy defined by the profit motive and market principle, Polanyi postulated a 'substantive' economic concept. It was grounded in the necessity for humans to provide a livelihood for themselves within a communal context, rather than doing so with their own advantage in mind.

While Polanyi exerted little direct influence on ancient economic historians of his time, his anti-modernist stance strongly resonated in Moses Finley's The Ancient Economy (1973), one of the most influential works of ancient history in the twentieth century. ${ }^{68}$ Theoretically eclectic and not particularly novel in any of its detail, The Ancient Economy designed an overall model of the ancient economy that combined well-selected source material into a radically new approach to the ancient economy. It was an attack both against the modernizing assumptions of earlier economic historians, and against the positivistic method of data collection that characterized their research. He also argued strongly against Marxist positions which had infiltrated economic history not only in Eastern Europe but also Western Germany, Italy, France and Britain during the 1960s and early 1970 s. ${ }^{69}$ In return, he offered a powerful framework for the analysis of the structural differences between the ancient and modern economies. These included the predominance of the agrarian household over market exchange; the importance of social status as against economic class; a particular kind of hierarchical social relationships in which slave labor dominated production; a particular relationship between town and countryside; and the priority of politics over economics, the latter being nonexistent as a separate discourse, or unit of analysis, in ancient states.

66 Polanyi 1957a.

67 Polanyi 1963; cf.1957a.

68 Finley had collaborated with Polanyi at Columbia University, but it came to an end with the expulsion of Finley from Rutgers University, Nafissi 2005, 209-214.

69 Nafissi 2005, 205-208 for Finley’s Marxist orientation during his early career. 
According to Finley, the ancient economy was a subsistence economy characterized by domestic self-sufficiency and the ideal of political autarky. The basis for all wealth was agriculture. Due to the availability of slave labor, the productivity of this agricultural domain never increased substantially, nor was it made more efficient through significant technical development. There was no economic growth in real terms. Within the economy as a whole, trade played only a minor role. Land transport was expensive, while sea transport risky and, with a few exceptions, concentrated on the import of luxury goods for consumption by a small elite. Cities did not specialize in any branch of production or manufacture that would have stimulated the division of labor, markets, and trade. Cities, in contrast to their industrialized counterparts, were political-religious centers of administration and representation, rather than centers of production. There were no rational individuals who made cost-benefit calculations in order to effectively increase the productivity of their land, or reinvested any profit in order to increase profitability through technological improvement or agricultural intensification. Wealth and surplus were invested into conspicuous consumption for the purpose of maintaining status and power. Loans were also used for consumption purposes only, to finance monetary dowries, or to compensate for temporary liquidity problems. Money was not capital but coinage, the minting of which was aimed at the self-representation of poleis and not at facilitating trade. In general, the politics of the states and their weak bureaucracies were directed toward self-representation, as well as the coverage of their own above all military - expenditure, and finally the allocation of honorary positions. There was neither an economic policy nor economic theory.

Finley's model of a 'primitive' non-dynamic economy has been more frequently criticized than praised. However, his insistence on approaching the ancient world conceptually, rather than arguing with selected quantities of evidence and common sense, has transformed research in ancient history beyond the ancient economy. And while many archaeologists, numismatists, and ancient historians have called into question the largely literary foundation to Finley's claims, with all the implications of social and geographical biases and stylization therein, no economic historian of the ancient world nowadays can go back to the descriptive positivism of much of pre-Finleyan economic history writing.

\section{II.4 Back to Economic Growth: The Work of Keith Hopkins and Beyond}

As early as 1978, Keith Hopkins wrote an essay on the question of economic growth in antiquity. ${ }^{70}$ In 1980 he published another influential article that developed a new methodological approach for studying the ancient economy, a new model for the

70 Hopkins 1978; cf. 1983. 
study of economic growth, and a model for the political economy of the Roman Empire. ${ }^{71}$ But he did not return to the modernist alternative. Hopkins proposed that in the long period from the first millennium BCE until the end of the second century $\mathrm{CE}$, there had been economic growth in the Graeco-Roman region, which accelerated in the Roman Empire from the second century BCE onward. This growth had several reasons: (1) an increase of agricultural production as a result of the increase of the area under cultivation; (2) population growth and an increase in population density; (3) an increase in the proportion of the population that was not active in the agricultural sector; (4) an increase in the production volume per capita; (5) an increase in production for tax purposes; and (6) a redistribution of taxes from more productive to less productive areas of the Roman Empire and to the Roman frontiers. Methodologically, Hopkins broke new ground by trying to provide quantitative evidence volumes of coinage and shipwrecks - for his theses. His taxes-and-trade model also suggested new ways of thinking about the relationship between the city of Rome, its provinces and the armies stationed to secure the Roman frontiers. ${ }^{72}$

Hopkins's hypotheses still form the starting point of many archaeological and historical research projects on the ancient economy. At first, however, his quantifying methodology, still in its infancy, was criticized from several angles. From a numismatic point of view, it was questioned whether the evidence from coin hoards could be extrapolated to quantify coin volumes in circulation and degrees of monetization. ${ }^{73}$ Shipwreck evidence, because of recovery rates and the constraints of maritime archaeology, also does not lend itself easily to long-term analyses of the rise and decline of seaborne trade. ${ }^{74}$ A large number of studies, moreover, took issue with Hopkins's circulation and integration model (thesis 6). ${ }^{75}$ This was based on the assumption that taxes in the Roman Empire were levied primarily in money, which was rightly called into question. Other forms of monetary and nonmonetary taxes and tributes were raised, forming a substantial part of the empire's income. The question of the extent to which the Roman Empire formed an economically integrated zone during the Roman Empire is still controversial. Adherents to the integration model of the Roman market economy include Temin and Geraghty. But despite their attempts, data are not sufficiently robust to prove an integrated market economy that was based primarily on the laws of supply and demand. ${ }^{76}$

The publication of the Cambridge Economic History of the Greco-Roman World marked a turning point in research on the ancient economy. Not only did it organize the current state of knowledge into a comprehensive multiauthored set of re-

71 Hopkins 1980.

72 Hopkins (1995-1996) 2001 discussed this relationship with a new emphasis on the city of Rome as a consumption center driving trade and economic performance (see also above, n. 36).

73 E.g., Duncan-Jones 1989; Howgego 1992.

74 Kitchen 2001.

75 E.g., Jongman 1988; Howgego 1994; Woolf 1992.

76 Rathbone and von Reden 2015. 
gional and chronological surveys, but it also set a new common agenda for the study of the ancient economy. Based on the neo-institutional approach to economic history developed by Douglass North, the editors defined the task of economic history as to explain economic performance through time. While being cautious not to overemphasize economic growth in terms of per capita increase in productivity, ${ }^{77}$ they suggested that the population of the Mediterranean perhaps doubled between ca. 800 BCE and $200 \mathrm{CE}$ and that there was a measurable increase in per capita consumption over the long-term. ${ }^{78}$ Emphasizing explanation and quantification rather than description and evaluation, they proposed a social science approach to economic history in contrast to the traditional humanistic methodology that characterized most ancient history writing. Already in 2005, Morris and Manning had developed a methodological catalog for such an approach. They suggested, (1) to make definitions of key terms and underlying assumptions clearer; (2) to be more explicit about processes and model building; (3) to present clear propositions and testable implications; (4) to be explicit about methods and standards of falsification; (5) to break large problems down to smaller, more answerable questions; (6) to specify causal relationships; (7) to quantify wherever possible; and (8) to formulate descriptions and explanations in ways that can be generalized to allow comparisons between different regions and periods. ${ }^{79}$

Neo-institutional economics, moreover, offered a number of conceptual tools and models with which economic performance could be explained. Central among these are institutional change, in particular the structure of property rights, the nature of transaction costs, the role of the state as well as the development of knowledge, including technological change, communication, and transport costs. Not all authors of the CEHGRW followed the call, and not all sets of ancient evidence easily lend themselves to answering the questions that neo-institutional economic poses, but the approach, and the volume of knowledge that the CEHGRW assembled, marked a starting point for increasingly scientific, quantitative, and comparative research in ancient economic history. As a result, economic historians have made greater use of the ever-increasing body of documentary evidence (papyri, coins, and inscriptions), and of new quantifiable data generated by archaeological research.

Parallel to, but not in tandem with, the development of the social science orientation of ancient economic history, archaeological science underwent fundamental changes. Since the 1960s, anthropological archaeologists under the umbrella term of New or Processual Archaeology had explored new theoretical and empirical

77 Per capita increase of productivity, according to classical economic theory, is the only basis for economic growth in real terms, while aggregate increase of wealth may be the result just of more efficient mobilization or concentration of wealth. If approached from classical economic theory, the only growth that matters is per capita increase of productivity; see Saller 2001 for discussion.

78 Morris, Saller, and Scheidel 2007, 6-11.

79 Morris and Manning 2005, 35. See now Canevaro, Erskine, Gray, and Ober 2018. 
methods in order to gain a more rigorous understanding of settlement structures, cultivation methods, subsistence strategies, energy provision, consumption patterns, trading behavior, forms of long-distance interaction and exchange, migration, and their ecological and environmental condition. ${ }^{80}$ Prehistoric archaeology, that is, archaeology in regions where written evidence is scarce or absent, has opened up new areas and landscapes for economic research. Maritime archaeology, archaeobotanical research, skeletal analyses, and paleoclimatology offer new opportunities for assessing more precisely the directions and scales of trade, standards of living, the productivity of human landscapes, maritime technologies, and the economic consequences of climate change. The volumes of the OxRep as well as their website have assembled bodies of quantitative evidence and tested new methods of analyzing large corpora of archaeological and documentary data. The intent of this work is to gain a more differentiated understanding of regional diversity and the conditions of economic performance related to agriculture, settlement, urbanization, and trade. $^{81}$

Globalization has changed how academics think. As Manning and Morris wrote in 2005, "Finley's was an ancient Mediterranean of divisions, rigid structures, and powerful institutions; Horden's and Purcell's is one of mobility, connectivity, and decentring." 8220 years further on, the laboratory in which Greek and Roman historians analyze mobility, connectivity, and decentering has become bigger.

\section{II.5 The Ancient Economy Turning Global}

For a variety of academic and contemporary reasons, there has been an increasing interest in global comparison, global trade, and global networking processes. ${ }^{83}$ Some Bronze Age archaeologists argue that the Afro-Eurasian region, or some zones within it, formed a world system as early as the third millennium BCE, ${ }^{84}$ that is, that they formed a space in which places interacted sufficiently to shape each other's economic and cultural development. ${ }^{85}$ Historians of later periods, including Immanuel Wallerstein himself, were rather more hesitant to identify world systems in the ancient world. ${ }^{86}$ Yet the concepts of world systems theory have profoundly influenced postcolonial, globalization, and empire studies. ${ }^{87}$ The discussion in ancient

80 Binford 1962; Clarke 1968; Renfrew and Bahn 1991; Wells 1992.

81 Bowman and Wilson 2009; 2011; 2013; 2018; Weaverdyck, ch. 8.A, this volume.

82 Morris and Manning 2005, 21-22.

83 With a particular focus on an economic issue, Monson and Scheidel 2015.

84 Sherrat and Sherrat 1993; Woolf 1990; Morley 2007b. For a stimulating summary of the original model, see Wallerstein 2004.

85 Kardulias and Hall 2008, 274-275; cf. Chase-Dunn and Hall 1997; Kuzmina and Mair 2008.

86 Chase-Dunn and Hall 1997, 41-75; Woolf 1990; cf. Wallerstein 1974, 15-16.

87 Morley 2007b; el-Ojeili 2014; Pitts and Versluys 2015. 
history about world systems stimulated debate over the significance of imperial peripheries and their role in transimperial exchange. The pioneering study by Philipp Curtin already focused on what he called trade diasporas in border zones: tightly organized merchant communities of the same cultural origin that provided protection and security for those engaging in commercial activities with the host community. ${ }^{88}$ More recently, scholars have described how host communities in border zones (both ecological and imperial) select or reject outside groups on the basis of their own needs or benefits. ${ }^{89}$ Research on frontier zone and borderland processes between ecologically different communities have qualified the picture of external trade as an unproblematic in- and outflow of goods between empires. ${ }^{90}$

Frontier zones as regions of economic development and cross-border contact have been studied mostly in connection with the Roman army. The military securing of frontiers shifted large numbers of soldiers to the borders of the Roman world. ${ }^{91}$ The question of the supply of these armies with food, equipment and other daily requirements has led to intensive research on the impact of the presence of the Roman legions as a local economic factor of frontier zones. Were soldiers supplied through requisition, local trade, trade over long distance, or the development of agrarian land in the frontier region? In what ways did the presence of soldiers and their demands encourage cross-border exchange either in the form of trade or diplomatic exchange of gifts? Answers vary, depending on the nature of the frontier, the nature of the supplies, and the evidence available. ${ }^{92}$ Frontier zones in Britain, North Africa, along the Danube, and the Eastern Desert have been researched intensely. The amount of economic and infrastructural development in North Africa and Egypt are particularly well studied, but they were of a very different kind, undertaken for different reasons, and with different effects. In North Africa, the evidence for agrarian development, the development of the olive industry and the export of olives had massive effects on markets throughout the Roman Empire. In the case of the Egyptian Eastern Desert, the development of roads, praesidiae (forts), and wells in connection with the exploitation of stone from Mons Claudianus and Porphyrites much facilitated the transport of luxury goods from the Red Sea harbors, Arabia, and India. ${ }^{93}$ The questions of how and in what ways these infrastructures affected markets and consumption within and outside the Roman Empire - or in Bowman and Wilson's terms, in what ways they were part of a trade system - are only beginning to be asked.

88 Curtin 1984, 1-3.

89 Morris 1999; Kardulias 2007; Kardulias and Hall 2008; Shaw 1990 and Purcell 2017.

90 Ray 2003; Thomas 2012.

91 See Weaverdyck, ch. 7 this volume, and Speidel below.

92 Cherry 2007, 726-733.

93 Cobb 2019; Schneider 2019. 


\section{Michael Speidel \\ III Historiographic Trends in Roman Frontier Studies}

\section{III.1 Introduction}

Rome's borders, and the eminent importance the Romans assigned to them are as old as the city itself. Tradition maintained that Rome's founder, King Romulus, personally ploughed the original line of the city's religious boundary, the pomerium, and built a wall around the earliest settlement. Both Rome's boundary and its protection were therefore considered to be essential to the very existence of the city from its earliest days onward. This is also borne out by the introduction of the new god Terminus, soon identified as an aspect of Rome's supreme god Jupiter, during the reign of Romulus (or that of his successor king Numa), as this god protected boundary markers and guaranteed peace.

The Roman Republic that was established after the last king was overthrown continuously expanded the often seemingly ill-defined boundaries of Roman power and influence, moving them ever further away from the city which thereby turned into an imperial capital. By the reign of Augustus (30 BCE-14 CE), Virgil, the poet of Rome's national epos, purported the empire to be one "without borders." 94 By the end of Augustus's reign, Roman expansion came to a near halt and the newly established standing army was moved to the Rhine, the Danube, and to the Euphrates, as well as to strategic positions in the Near East, Egypt, and North Africa. Before a century was over, durable fortresses and defenses were erected and proclaimed to protect the empire. With comparatively minor adjustments, but with the addition of Britain under Claudius in 43 CE and Dacia under Trajan in 106, these remained operational until around the early years of the fifth century CE when foreign invasions, civil wars, and weakened defenses wrenched control of the former frontiers from the central government and set the scene for the collapse of the Western Empire.

Boundaries, frontiers and defense systems thus played a very visible and important role throughout Roman history. In order to understand the directions of modern historiographic trends, it is essential to realize that the surviving ancient narratives and other written sources have deeply influenced the ways in which modern historians thought about Rome's borders and frontiers. Thus, ancient historiography only rarely focuses on the history of frontiers and frontier zones as a subject in its own right. On the few occasions when frontiers are mentioned, it is almost exclusively in the context of military conflicts with Rome's external neighbors. Unless these 'barbarians' beyond the frontiers were allied with the empire, ancient historiography tended to portray them as hostile and bellicose, some to the point that "they do

94 Virgil, Aeneid (Virg. Aen.) 1. 279; Harris 2016. 
not even understand what peace is." 95 In modern historiography, frontiers therefore became a subject of military history. During the Republican period, however, in which Rome expanded primarily at the expense of communities in Italy and Greece, Carthage in North Africa, Spain, and the Hellenistic kingdoms in the East, outer borders hardly ever surface in the ancient texts and are thus missing in modern accounts. Perhaps the reason for their near absence in historical texts was that Rome, rather than setting new external borders, usually took over those of the powers it subjugated. Exceptional mentions of boundaries are few, though one might note the so-called Ebro treaty of ca. 226 BCE, according to which the river Iber was identified as the border between the sphere of influence of Carthage and Rome on the Iberian Peninsula. The Carthaginian breach of this treaty is said to have caused the Second Punic War (218-201 BCE).

\section{III.2 Changing Perspectives}

Evidently, this episode and its sources have been thoroughly studied by modern historians. Yet only the more-or-less static frontiers of imperial Rome suggested themselves forcefully to modern scholars as a complex subject worthy of intensive scholarly attention in a time when the rising European colonial powers began to view their own 'civilizing mission' as one that followed in Roman footsteps. When the focus of scholarly interest first fell on imperial frontiers, they began to be studied within the broad narrative frame of an epic clash of cultures in which one (the Greeks and Romans) was eminently superior and had the divine mission to push back the other, inferior culture (the 'barbarians' beyond the frontiers) or at least to keep it at bay. The significance of the empire's frontiers was thus seen to lay in their function as a dividing line between what was understood to be the civilized world on the one side and a world on the other in which civilization was absent. Such views were of course deeply rooted in the transmitted narratives from the ancient world, in which humanitas ('civilization') was a wholly Roman concept and contrasted sharply with the strange, ferocious and irrational ways of the 'barbarians.'96 Yet, within the empire, humanitas could be acquired through a process of assimilation. Hence, modern historiography believed that those peoples, communities, and landscapes absorbed and subjugated to Roman control eventually transformed as a whole. They adopted Roman ways of life, architecture, and culture, learned Latin and thus elevated to a higher degree of civilization, in a process Theodor Mommsen referred to by the term "romanization". 97

95 Tanta barbaria est ut nec intellegant pacem, Florus (Flor.) 2. 29, in the early second century CE on the Sarmatians.

96 Woolf 1998, 54-67.

97 Mommsen 1885, ch. 2. 
At any rate, it is perhaps hardly a coincidence that the interpretation of the empire's northern frontier in Britain that the eminent English historian Edward Gibbon (1737-1794) advanced set the tone for much of the ensuing discourse:

This wall of Antoninus, at a small distance beyond the modern cities of Edinburgh and Glasgow, was fixed as the limit of the Roman province. The native Caledonians preserved in the northern extremity of the island their wild independence, for which they were not less indebted to their poverty than to their valour. Their incursions were frequently repelled and chastised; but their country was never subdued ... The masters of the fairest and most wealthy climates of the globe turned with contempt from the gloomy hills assailed by winter tempests, from lakes concealed in a blue mist, and from cold and lonely heaths over which the forest deer were chased by naked barbarians. ${ }^{98}$

Independence was the only positive aspect of their existence, but even that was owed to their own ignorance, brutality and greed as well as to the unwillingness of the civilized to welcome the wild and naked into their world. Rome's downfall was understood as a consequence of its failure to ultimately keep the 'barbarians' out.

Cold, poverty and a life of danger and fatigue fortify the strength and courage of barbarians. In every age they have oppressed the polite and peaceful nations ... who neglected, and still neglect, to counterbalance these natural powers by the resources of military art ... The splendid days of Augustus and Trajan were eclipsed by a cloud of ignorance, and the barbarians subverted the laws and palaces of Rome. ${ }^{99}$

According to the traditional view, imperial Rome established its external borders from the very beginning with the intention to defend the empire and to keep the 'barbarians' out. ${ }^{100}$ The significance of its frontiers was seen to have shifted over the centuries from open, moving zones of an expanding empire to closed, static lines of defense. The physical barriers, natural or erected, that surrounded the provincial territory came to be understood as military, moral, ideological and cultural barriers separating civilization and law from barbarism and lawlessness. ${ }^{101}$ This largely remained to be the case even after the discovery of a gate through Hadrian's Wall already in 1848 gave rise to criticism of the wall's supposed impermeability. ${ }^{102}$ To some, however, the existence of a gate suggested that "the people north of it [the Wall] were not very formidable" after all. ${ }^{103}$ To most, however, Rome's boundaries continued to be above all a geopolitical subject, a major part of the empire's military infrastructure, and one that needed to be studied within the framework of Roman army studies. The end of the frontiers, and indeed the fall of the Western Empire in

98 Gibbon 1776, 1.

99 Gibbon 1781, 637 and 640.

100 Rice Holmes 1928-1931, 2:164-165; Syme 1934, 352-354; Wells 1972, 152.

101 Alföldi 1952; Miller and Savage 1977.

102 Breeze 2018a, 166.

103 Anonymus 1898, 49. 
$476 \mathrm{CE}$, naturally found their explanations within this narrative frame. Allegoric floods and dykes (thus natural disasters against man-made protections) determined the narratives of these developments. The recruitment of increasing numbers of foreign, even 'barbarian' soldiers and mercenaries into the Roman army, an ensuing decline of military discipline, and neglect to defend the borders were the main reasons believed to have led to the fall of the Western Empire in $476 .{ }^{104}$ Such views shaped and sometimes dominated the debate about Roman frontiers until the later twentieth century and are still regularly discussed in attempts to describe the current state of Roman frontier studies. ${ }^{105}$

Such were the insights most nonspecialists took away, and often still do, from the published literature on Roman frontiers or from their own studies of the written sources and archaeological remains. Thus, for instance, Lord Curzon of Kedleston, Britain's viceroy of India from 1899 to 1905, who was praised for his attempts to bring stability to the Indian frontier, was inspired by the history of Rome's frontiers, even though he later erroneously claimed that scholars had "almost wholly ignored" the subject. ${ }^{106}$ According to him, the Roman Empire was "nowhere so like our own as in its Frontier policy and experience." In his view, India's northwest frontier could therefore compare "point by point with its ancient counterpart and prototype, the frontier system of Rome.” C. Collin Davies, the historian and author of a classic study on British India's north-west frontier even concluded: "Rome fell because her dykes were not strong enough to hold back the flood of barbarian inroads."107 Rudyard Kipling's descriptions of Hadrian's Wall in Puck of Pook's Hill (1904) and of its meaning for the Roman Empire were inspired by the same images, and the British experience of empire.

The study of Rome's desert frontiers, too, was influenced by nineteenth-century European imperial history and colonial experience. Thus, Lord Curzon explained the absence of linear frontier barriers and legionary and auxiliary fortresses strung out on from the edges of the deserts in North Africa and the Near East by referring to Napoleon I, who judged that the desert was sufficient barrier and the most effective kind of frontier. ${ }^{108}$ The French in North Africa, believing in their 'mission civilisatrice,' saw themselves as heirs to the Romans. ${ }^{109}$ With respect to the North African frontier zones, their focus was set on the relations and interactions between the nomadic and the sedentary populations. Hence, interpretations of the Roman barriers in North Africa, the so-called Fossatum Africae, almost invariably "relate to observations of French colonial officials on transhumance in the land between the

104 Von Domaszewski 1914, 256; $1967^{2}, 88$.

105 E.g., James 2005; Hingley 2017; Breeze 2018a and b.

106 Curzon 1907, 4-5; ibid. 8 and 54 for the following quotations; cf. Whittaker 2004.

107 Davies 1932, 2.

108 Curzon 1907, 15-16; cf. Birley 2002a, 2.

109 Baradez 1949, 362. 
desert and the cultivated areas, either supporting or challenging their interpretations."110

Yet, even within Europe, interpretations of imperial Rome's frontiers were anything but irrelevant as they could take on hotly debated political dimensions. This is perhaps most evident in the centuries-long dispute about the meaning of the Roman Rhine frontier for French or Roman rule over the Alsace. ${ }^{111}$ Famously, this dispute was fueled by the discovery, in the sixteenth century, of Tacitus's Germania, which provided a Latin text of great authority to counterbalance Julius Caesar's claim that the Rhine marked the borders of Gaul. When France's defeat in the Franco-Prussian War of 1870/71 led to its loss of Alsace and Lorraine, two eminent ancient historians of their respective countries, Numa Denis Fustel de Coulanges and Theodor Mommsen, publicly exchanged arguments, based in part on their knowledge of the ancient sources, for and against the Rhine as the border between France and Germany.

From a structural perspective, however, the academic study of the Roman frontiers developed as a branch of Roman archaeology with a strong input by ancient history, and was initiated in the nineteenth century in Britain and Germany. The beginnings of research on imperial frontiers in Britain (mainly of course Hadrian's Wall), is closely tied to the name of John Collingwood Bruce, a Newcastle clergyman who produced a long series of publications about Hadrian's Wall and who initiated the tradition of an organized walk along the Wall, the so-called Pilgrimage that began in 1849 and has continued every 10 years since 1886 except for the war years. ${ }^{112}$ Scientific studies of the Wall were carried out and published by the local English and Scottish archaeological societies. In Germany, after half a century of debate, the centralized state-run Reichslimeskommission (RLK) was established in 1892 under the leadership of the newly united country's leading ancient historian Theodor Mommsen. The Kommission was funded and supported by the new German imperial government in order to work out the route and document the remains of the Roman frontier, its defenses as well as its associated forts and military installations north of the Alps on the territory of the Kaiserreich. Kaiser Wilhelm II publicly expressed his support of this enterprise by extending his patronage for the reconstruction of the Roman fortress at the Saalburg. Between 1894 and 1937 the RLK, which in 1902 passed under the directorship of Ernst Fabricius, professor of ancient history in Freiburg, published the results of its work in 56 installments of its publication series Der obergermanisch-rätische Limes des Römerreichs. This major achievement had its clear impact on future studies of the Roman frontiers as it appears to have encouraged a reducing of the subject to linear barriers and strings of heavily garrisoned forts.

110 Wells 1991, 478; Breeze 2018a, 165.

111 Whittaker 2004, 187-189.

112 Birley 2002a, 1. 
The two world wars not only interrupted many archaeological and historical projects and studies as well as ties between colleagues of different nations, they also had various other impacts on the ways scholars began to interpret Roman frontiers. ${ }^{113}$ Trench warfare in particular appears to have inspired interpretations of Roman warfare and defense lines after the First World War. ${ }^{114}$ On the whole, however, the Roman army's role as a fighting force was marginalized after the Second World War as a field of scholarly research, above all in German speaking academia. The appalling war experiences many archaeologists and historians of the Roman frontiers had personally suffered or witnessed, as well as the emergence of the Iron Curtain, now began to influence Roman frontier studies. ${ }^{115}$ Thus, the study of all forms and aspects of violence including the study of battles, military equipment and techniques were considered repugnant and distasteful. ${ }^{116}$ Instead, questions pertaining to the structures and organization of the army and to the military organization of the frontiers now took center stage. ${ }^{117}$

Since 1949, Roman frontier studies have developed largely (though not exclusively) through the medium of the (usually) triennial international Roman Frontier Studies Congress or Limes Congress, which convenes at changing locations with access to archaeological sites on the Roman frontiers. Initiated by Eric Birley from Durham University, the later Life President of the Congress, with the intention to promote the exchange of British and foreign scholars working on Roman frontiers, the Limes Congress has become one of the oldest periodic conventions in the studies of the ancient world. Initially, the dominant tradition displayed through these Congresses was to uncover (by excavation and survey), to record, and to reconstruct the physical remains of infrastructure of the Roman army in the frontier regions of the empire. Organizational questions regarding the Roman army, imperial wars and military infrastructure, chronologies, archaeological typologies, and general augmention of our databases of archaeological and historical information on such matters were the prime objectives of the presentations at the Limes Congresses. ${ }^{118}$ Soon, however, the global political situation of the time began to show its impact on the way in which scholars thought about Roman imperial frontiers. Cold War logic, in any event, was in full accord with the main statement of an influential paper presented by Eric Birley in 1955 on Hadrianic frontier policy at the second Congress in Carnuntum, Austria in which the author argued that it was an intention of Roman frontiers to protect the empire's inhabitants from foreign attacks and of the Roman

113 Whittaker 2004, 186.

114 Breeze 2018a.

115 Alföldi 1952.

116 James 2002, 12-14.

117 James 2002, 13-14, 21; Breeze 2018a, 166.

118 Birley 2002a. 
army to provide the safety that was necessary for the economic exploitation of the lands. ${ }^{119}$

Also much-inspired by Cold War thinking was Edward N. Luttwak's The Grand Strategy of the Roman Empire from 1976. The author, a modern US strategist and outsider to studies of the ancient world, was the first to offer a coherent narrative of the Roman Empire's military strategy along its frontiers based on the available archaeological and historical sources (mainly fortification placement and transmitted military operations). His reconstructions of Roman Grand Strategy were heavily inspired by assumptions relevant to Cold War scenarios and the defense of the West against threats from the communist East rather than by concepts and structures from the Roman world, and have therefore been widely rejected by historians of the Roman Empire. ${ }^{120}$ Luttwak's book was nevertheless highly influential as the rejection of its conclusions sparked not only a lively (often heated) debate among those engaged in Roman frontier studies about the empire's frontier strategy. ${ }^{121}$ But it also raised new questions of how to define this field of study. ${ }^{122}$ It substantially increased efforts to understand the history of the imperial frontiers and the role of the army in order to include new and different aspects to the hitherto predominant (though never entirely exclusive) studies of the frontiers as military defenses of the empire against external threats along physical barriers. In particular, the cultural and economic impact of the army's presence, the daily life of its soldiers, and the various ways in which they were a burden on the population of the frontier zones became an increasingly popular research subject. ${ }^{123}$

In the wake of these developments, a group of initially mainly British ancient historians and archaeologists began to voice criticism of the traditions of the Limes Congresses, calling for a move away from the study of Roman fortifications and military strategies against external threats, as well as from the constraints imposed by the traditional set of written sources, and for the development of a broader concept of Roman frontiers that gives priority to wider social and economic aspects. ${ }^{124}$ The traditional approach toward Roman frontier studies as represented by the Limes Congress was accused of being "unduly narrowly focused and obsessively concerned with pointless minutiae," "introverted," "far too parochial for its own (or anybody else's) good," "predominantly conservative," and "permanently suspicious of innovation, especially in theory," while being mostly preoccupied with the wrong kind of questions. ${ }^{125}$ The effects of Rome's frontiers on the local populations and

119 Birley 1956.

120 Mann 1979; Millar 1982; Isaac 1990; Whittaker 1994, 62-66.

121 Wheeler 1993; Breeze 2011; Breeze 2018b.

122 Isaac 1990.

123 E.g., Bowman 1994; Birley 2002b; Erdkamp 2002.

124 Isaac 1990; Whittaker 1994; Elton 1996; Mattingly 1997; James 2005; Gardner 2013; Gardner 2017.

125 James 2005, 499, 501-502; Breeze 2018b, 2. 
the threat by external forces were considered far less significant than previously thought. ${ }^{126}$ The processes and results of 'romanization' were reinvestigated and found to be far more complex and diverse than many had previously held. ${ }^{127}$ Even the view, accepted since Gibbon, that the pax Romana meant general peace and prosperity within the empire was challenged with reference to attested domestic and juridical violence. ${ }^{128}$ Although much of the critique and call for innovation was no doubt justified and resulted in fruitful debates and inspiring new contributions, they were not always free of exaggerations and omissions of existing alternative views, particularly in other national traditions and their publications.

Since the 1980s and 1990s, increased attention has thus been directed toward the complexities of the interactions between native peoples under Roman domination and the representatives of the empire. As a result, it became increasingly common to study frontiers not so much as fortified linear military barriers but as zones of a specific nature in which cultural, social, and economic aspects played a prominent role. ${ }^{129}$ Theory and models came to be favored, ${ }^{130}$ which unsurprisingly also encouraged cross-cultural and cross-temporal comparative studies, ${ }^{131}$ as well as studies investigating interpretations of the Roman army with regard to contemporary theories of migration and globalization. ${ }^{132}$ It is now generally accepted that Roman frontiers cannot be understood in isolation from socioeconomic and cultural processes along, far behind, and far beyond the frontiers themselves. ${ }^{133}$ It has also been suggested that the frontier zone along the edge of the empire was indeed an important factor for the development and prosperity of the Roman state. ${ }^{134}$

\section{III.3 Long-Distance Trade and the Frontiers}

In addition to supplying the army, trade movement across the Roman frontier existed at all times. Mortimer Wheeler explored this important subject in his Rome beyond the Imperial Frontiers in 1954. It was recently again the subject of a collection of articles. ${ }^{135}$ The long-distance overland and maritime trade routes through Egypt, the Red Sea, the Arabian Peninsula and Mesopotamia had to cross Roman borders

126 Isaac 1990; Elton 1996; Whittaker 2004, 45-46.

127 Woolf 1998; 2014; Mattingly 2004; Versluys 2014.

128 Woolf 1993.

129 Isaac 1990; Whittaker 1994; Whittaker 2004; cf. James 2005; Hekster and Kaizer 2012; Hingley 2017.

130 Birley 2002a, 7; Hingley 2017.

131 Miller and Savage 1977; Breeze 2008; McWilliams 2011; cf. Hingley 2017, 2; Breeze 2018b, 3.

132 Hingley 2017; Breeze 2018a, 165.

133 Birley 2002a, 3; James 2005, 501.

134 Whittaker 1994; Whittaker 2004; cf. Speidel 2016, esp. 165.

135 Wells 2013. 
and frontier zones. Therefore, studies investigating trade between the Roman Empire and South Arabia, East Africa or India usually engage with questions pertaining to the Roman army and the empire's frontiers. ${ }^{136}$ In particular, the army's role in safeguarding trade routes and traders as well as its involvement in the collection of tolls and taxes have been repeatedly studied. ${ }^{137}$ Moreover, the mechanisms and effects of cross-border mobility on the Roman frontiers has received attention. Seen to be largely a result of trade and military activity, these types of mobility centralized the Roman frontiers as spaces which aggregated and disseminated information about various parts of the world, as far away as China. ${ }^{138}$ However, trade between the Roman Empire and the East is only rarely investigated by the same scholars who engage in Roman frontier studies or Roman army studies. Moreover, specialized and distinct academic disciplines often deal with just one side of Rome's former borders, for example in the Arabian Peninsula, Nubia, or North Africa, and lack sufficient knowledge of the sources, methods, institutions, and concepts of the other. Both of these obstacles stand in the way of a comprehensive and universal study of the frontier zones of the Roman Empire, which therefore remain under-researched in many of the respective areas.

\section{References}

Alcock, S. 2007. "The Eastern Mediterranean.” In Scheidel, Morris, and Saller (2007), 671-697.

Alföldi, A. 1952. "The moral barrier on Rhine and Danube." In E. Birley (ed.), The Congress of Roman Frontier Studies 1949, 1-16. Kendal: Titus Wilson \& Son.

Andreau, J. (1995) 2001. “Twenty years after Moses I. Finley's The Ancient Economy." In Scheidel and von Reden (2001), 33-52. Originally published as "Vingt ans après L'Économie antique de Moses I. Finley."

Anonymus 1898. "Report of a visit to Hadrian's Wall." Proceedings of the Society of Antiquaries of Newcastle upon Tyne 8, 46-53.

Austin, N. J. E., and N. B. Rankov. 1995. Exploratio: Military and political intelligence in the Roman world from the Second Punic War to the Battle of Adrianople. London: Routledge.

Baker, H. D., and M. Jursa, eds. 2014. Documentary sources in ancient Near Eastern and GrecoRoman economic history. Oxford: Oxbow.

Bagnall, R. S. 2005. "Egypt and the concept of the Mediterranean." In W. V. Harris (ed.), Rethinking the Mediterranean, 339-347. Oxford: Oxford University Press.

Ball, W. 2000. Rome in the East: The transformation of an empire. London: Routledge.

Bang, P. F. 2007. "Trade and empire: In search of organizing concepts for the Roman economy." Past and Present 195, 3-52.

-. 2008. The Roman bazaar: A comparative study of trade and markets in a tributary empire. Cambridge: Cambridge University Press.

136 Esp. Young 2001; Sidebotham 2011; Seland 2016; Cobb 2018; Nappo 2018.

137 Cuvigny 2003; Speidel 2016; Cobb 2018.

138 Lee 1993; Austin and Rankov 1995; Kolb and Speidel 2017. 
Baradez, J. 1949. Fossatum Africae: Recherches aériennes sur l'organisation des confins sahariens à l'époque romaine. Paris: Arts \& Métiers graphiques.

Binford, L. R. 1962. “Archaeology as anthropology.” American Antiquity 28, 217-225.

Bingen, J. (1978) 2007. "The Revenue Laws Papyrus: Greek tradition and Hellenistic adaptation.” In Hellenistic Egypt: Monarchy, society, economy, culture, 157-188. R. S. Bagnall (ed.). Edinburgh: Edinburgh University Press. Originally published as Le Papyrus Revenue Laws Tradition grecque et adaptation hellénistique.

Birley, A. R. 2002a. “Fifty years of Roman frontier studies.” In P. Freeman, J. Bennett, Z. T. Fiema, and B. Hoffmann (eds.), Limes XVIII: Proceedings of the XVIIIth International Congress of Roman Frontier Studies, held in Amman, Jordan (September 2000). Vol. 1, 1-11. Oxford: Archaeopress.

-. 2002b. Garrison life at Vindolanda: A band of brothers. Stroud: Tempus.

Birley, E. 1956. "Hadrianic frontier policy.” In E. Swoboda (ed.), Carnuntina: Ergebnisse der Forschung über die Grenzprovinzen des römischen Reiches: Vorträge beim internationalen Kongress der Altertumsforscher, 25-33. Graz: Böhlau.

Bowman, A. K. 1994. Life and letters on the Roman frontier: Vindolanda and its people. London: British Museum Press.

Bowman, A. K., and A. Wilson, eds. 2009. Quantifying the Roman economy: Methods and problems. Oxford: Oxford University Press.

-, eds. 2011. Settlement, urbanization, and population. Oxford: Oxford University Press.

-, eds. 2013. The Roman agricultural economy: Organization, investment, and production. Oxford: Oxford University Press.

-, eds. 2018. Trade, commerce, and the state in the Roman world. Oxford: Oxford University Press.

Breeze, D. 2008. “To study the monument: Hadrian's Wall 1848-2006.” In P. T. Bidwell (ed.), Understanding Hadrian's Wall: Papers from a conference held at South Shields, 3rd-5th November, 2006, to mark the publication of the 14th edition of the 'Handbook to the Roman Wall,' 1-4. South Shields: Arbeia Society.

-. 2011. The frontiers of imperial Rome. Barnsley: Pen \& Sword Military.

-. 2018a. "The role of Zeitgeist in understanding Roman frontiers." in C. S. Sommer and S. Matešić (eds.), Limes XIII: Proceedings of the 23rd International Congress of Roman Frontier Studies Ingolstadt 2015: Akten des 23. Internationalen Limeskongresses in Ingolstadt 2015. Vol. 1, 164-167. Mainz: Nünnerich-Asmus.

-. 2018b. "The value of studying Roman frontiers." Theoretical Roman Archaeology Journal 1, 1-17.

Bresson, A. 2014. "Capitalism and the ancient Greek economy." In L. Neal and J. Williamsen (eds.), The Cambridge history of capitalism. Vol. 1, 43-74. Cambridge: Cambridge University Press.

-. (2007-2008) 2016. The making of the ancient Greek economy: Institutions, markets, and growth in the city-states. S. Rendall (trans.). Princeton, NJ: Princeton University Press. Originally published as L'économie de la Grèce des cites. 2 vols.

Broodbank, C. 2013. The making of the Middle Sea: A history of the Mediterranean from the beginning to the emergence of the classical world. London: Thames \& Hudson.

Brown, P. 2018. “'Charismatic' goods: Commerce, diplomacy, and cultural contacts along the Silk Road in Late Antiquity." In N. Di Cosmo and M. Maas (eds.), Empires and exchanges in Eurasian Late Antiquity, 96-107. Cambridge: Cambridge University Press.

Bücher, K. 1893. Die Entstehung der Volkswirtschaft. Tübingen: Mohr.

Burkert, W. (1984) 1992. The orientalizing revolution: Near Eastern influence on Greek culture in the early Archaic age. M. E. Pinder (trans.). Cambridge, MA: Harvard University Press. Originally published as Die orientalisierende Epoche in der griechischen Religion und Literatur. 
Burkhardt, J., O. Oexle, and P. Spahn. 1992. "Wirtschaft." In O. Brunner, W. Conze, and R. Koselleck (eds.), Geschichtliche Grundbegriffe: Historisches Lexikon zur politisch-sozialen Sprache in Deutschland. Vol. 7, 511-594. Stuttgart: Klett.

Canevaro, M., A. Erskine, B. Gray, and J. Ober. eds. 2018. Ancient Greek history and comtemporary Social Science. Edinburgh: Edinburgh University Press.

Carrier, J. G. 2012. “Introduction.” In J. G. Carrier (ed.), A handbook of economic anthropology. 2nd ed., 1-12. Cheltenham: Edward Elgar.

Cartledge, P. 1993. The Greeks: A portrait of self and others. Oxford: Oxford University Press.

Chase-Dunn, C., and T. D. Hall, eds. 1997. Rise and demise: Comparing world-systems. Boulder, CO: Westview.

Cherry, J. 2007. "The frontier zones." In Scheidel, Morris, and Saller (2007), 720-741.

Clarke, D. L. 1968. Analytical archaeology. London: Methuen.

Cobb, M. A. 2018. Rome and the Indian Ocean trade from Augustus to the early third century CE. Leiden: Brill.

-. 2019. "From the Ptolemies to Augustus: Mediterranean integration into the Indian Ocean trade." In M. A. Cobb (ed.), The Indian Ocean trade in antiquity: Political, cultural and economic impacts, 17-51. London: Routledge.

Curtin, P. D. 1984. Cross-cultural trade in world history. Cambridge: Cambridge University Press.

Curzon, G. N. 1907. Frontiers. Oxford: Oxford University Press.

Cuvigny, H., ed. 2003. La route de Myos Hormos: L'armée romaine dans le desert orientale d'Égypte. 2 vols. Cairo: Institute français d'archéologie orientale.

Davies, C. C. 1932. The problem of the north-west frontier 1890-1908: With a survey of policy since 1849. Cambridge: Cambridge University Press.

De Romanis, F., and M. Maiuro, eds. 2015. Across the ocean: Nine essays on Indo-Mediterranean trade. Leiden: Brill.

Duncan-Jones, R. 1989. "Mobility and immobility of coin in the Roman Empire." Instituto Italiano di Numismatica 36, 121-137.

Eich, A. 2006. Die politische Ökonomie des antiken Griechenland (6.-3. Jahrhundert v. Chr.). Cologne: Böhlau.

El-Ojeili, C. 2014. "Wallerstein: The modern world-system: Four decades on." Critical Sociology 40.1, 1-22.

Erdkamp, P., ed. 2002. The Roman army and the economy. Amsterdam: J. C. Gieben.

Elton, H. 1996. Frontiers of the Roman Empire. London: Batsford.

Evers, K. G. 2017. Worlds apart trading together: The organisation of long-distance trade between Rome and India in antiquity. Oxford: Archaeopress.

Finley, M. I. (1973) 1985. The ancient economy. London: Chatto \& Windus.

Finley, M. I., ed. 1979. The Bücher-Meyer controversy. New York, NY: Arno.

Fitzpatrick, M. P. 2011. "Provincializing Rome: The Indian Ocean trade network and Roman imperialism." Journal of World History 22, 27-54.

Frier, B. W., and D. F. Kehoe. 2007. "Land and economic institutions." In Scheidel, Morris, and Saller (2007), 113-144.

Galli, M. 2017. "Beyond frontiers: Ancient Rome and the Eurasian trade networks." Journal of Eurasian Studies 8, 3-9.

Gardner, A. 2013. "Thinking about Roman imperialism: Postcolonialism, globalisation and beyond?" Britannia 44, 1-25.

-. 2017. "Roman Britain from the outside: Comparing western and northern frontier cultures." In S. González Sánchez and A. Guglielmi (eds.), Romans and barbarians beyond the frontiers: Archaeology, ideology and identities in the north, 34-47. Oxford: Oxbow.

Gibbon, E. 1776. The history of the decline and the fall of the Roman Empire. Vol. 1, London: Strahan \& Cadell. 
-. 1781. The history of the decline and the fall of the Roman Empire. Vol. 3, London: Strahan \& Cadell.

Graf, D. 2018. "The Silk Road between Syria and China.” In A. Wilson and A. K. Bowman (eds.), Trade, commerce, and the state in the Roman world, 443-532. Oxford: Oxford University Press.

Gregoratti, L. 2019. “Indian Ocean trade: The role of Parthia.” In M. A. Cobb (ed.), The Indian Ocean trade in antiquity: Political, cultural and economic impacts, 52-72. London: Routledge.

Harris, W. V. 2005. "The Mediterranean and ancient history." In W. V. Harris (ed.), Rethinking the Mediterranean, 1-44. Oxford: Oxford University Press.

-. 2016. Roman power: A thousand years of empire. Cambridge: Cambridge University Press. Hasebroeck, J. 1928. Staat und Handel im alten Griechenland. Tübingen: Mohr.

-. 1931. Griechische Wirtschafts- und Gesellschaftsgeschichte. Tübingen: Mohr.

Heichelheim, F. M. 1930. Wirtschaftliche Schwankungen der Zeit von Alexander bis Augustus. Jena: Fischer.

-. 1938. Wirtschaftsgeschichte des Altertums. 2 vols. Leiden: Sijthoff.

Hekster, O., and T. Kaizer, eds. 2012. Frontiers in the Roman world: Proceedings of the ninth workshop of the international network Impact of Empire (Durham, 16-19 April 2009). Leiden: Brill.

Herzfeld, M. 2005. "Practical Mediterraneanism: Excuses for everything from epistemology to eating." In W. V. Harris (ed.), Rethinking the Mediterranean, 45-63. Oxford: Oxford University Press.

Hingley, R. C. 2017. "Introduction: Imperial limits and the crossing of frontiers." In S. González Sánchez and A. Guglielmi (eds.), Romans and barbarians beyond the frontiers: Archaeology, ideology and identities in the north, 1-7. Oxford: Oxbow.

Hopkins, K. 1978. "Economic growth and towns in classical antiquity." In P. Abrams and E. A. Wrigley (eds.), Towns in societies: Essays in economic history and historical sociology, 3577. Cambridge: Cambridge University Press.

-. 1980. "Taxes and trade in the Roman Empire (200 BC-AD 400)." Journal of Roman Studies 70, 101-125.

-. 1983. “Introduction.” In P. D. A. Garnsey, K. Hopkins, and C. R. Whittaker (eds.), Trade in the ancient economy, ix-xxv. Berkeley, CA: University of California Press.

-. (1995-1996) 2001. “Rome, taxes, rents, and trade." In Scheidel and von Reden, 190-230.

Horden. P., and N. Purcell. 2000. The corrupting sea: A study of Mediterranean history. Malden, MA: Blackwell.

Howgego, C. 1992. "The supply and use of money in the Roman world, 200 BC to AD 300." Journal of Roman Studies 82, 1-31.

-. 1994. "Coin circulation and the integration of the Roman economy." Journal of Roman Archaeology 7, 5-21.

Humphreys, S. C. 1978. Anthropology and the Greeks. London: Routledge and Kegan Paul. Isaac, B. 1990. The limits of empire: The Roman army in the East. Oxford: Clarendon.

James, S. 2002. "Writing the legions." Archaeological Journal 159, 1-58.

-. 2005. "Limesfreunde in Philadelphia: A snapshot of the state of Roman frontier studies." Britannia 36, 499-502.

Jongman, W. 1988. The economy and society of Pompeii. Amsterdam: J. C. Gieben.

Jursa, M. 2014. "Introduction.” In H. D. Baker and M. Jursa (eds.), Documentary sources in ancient Near Eastern and Greco-Roman economic history, 1-6. Oxford: Oxbow.

Kardulias, P. N. 2007. "Negotiation and incorporation on the margins of world systems: Examples from Cyprus and North America." Journal of World Systems Research 31, 55-82.

Kardulias, P. N., and T. D. Hall. 2008. "Archaeology and world systems analysis.” World Archaeology 40, 572-581. 
Kitchen, K. 2001. "Economics in ancient Arabia: From Alexander to the Augustans." In Z. H. Archibald, J. Davies, V. Gabrielsen, and G. J. Oliver (eds.), Hellenistic economies, 157-173. London: Routledge.

Kolb, A., and M. A. Speidel. 2017. "Imperial Rome and China: Communication and information transmission." M. D. Elizalde and W. Jianlang (eds.), China's development from a global perspective, 28-56. Newcastel upon Tyne: Cambridge Scholars Publishing.

Kuzmina, E. E., and V. H. Mair, eds. 2008. The prehistory of the Silk Road. Philadelphia, PA: University of Philadelphia Press.

Lee, A. D. 1993. Information and frontiers: Roman foreign relations in Late Antiquity. Cambridge: Cambridge University Press.

Lo Cascio, E. 2007. "The early Roman Empire: The state and the economy." In Scheidel, Morris, and Saller (2007), 619-650.

Mann, J. C. 1979. "Power, force and the frontiers of empire." Journal of Roman Studies 69, 175-183.

Manning, J. G. 2007. “Hellenistic Egypt.” In Scheidel, Morris, and Saller (2007), 434-459.

Mathew, K. S., ed. 2015. Imperial Rome, Indian Ocean regions and Muziris: New perspectives on maritime trade. London: Routledge.

Mattingly, D. 2004. "Being Roman: Expressing identity in a provincial setting." Journal of Roman Archaeology 17, 5-26.

Mattingly, D., ed. 1997. Dialogues in Roman imperialism: Power, discourse, and discrepant experience in the Roman Empire. Portsmouth, RI: Journal of Roman Archaeology.

McLaughlin, R. 2014. The Roman Empire and the Indian Ocean: The ancient world economy and the kingdoms of Africa, Arabia and India. Barnsley: Pen \& Sword Military.

-. 2016. The Roman Empire and the Silk Routes: The ancient world economy and the empires of Parthia, Central Asia and Han China. Barnsley: Pen \& Sword History.

McWilliams, A. 2011. "All quiet on the eastern front." In D. Mullin (ed.), Places in between: The archaeology of social, cultural and geographical borders and borderlands, 13-22. Oxford: Oxbow.

Millar, F. 1982. "Emperors, frontiers and foreign relations." Britannia 13, 1-23.

-. 1998. "Caravan cities: The Roman Near East and long distance trade by land." In M. M. Austin and G. Rickman (eds.), Modus operandi: Essays in honour of Geoffrey Rickman, 275-299. London: Institute of Classical Studies, University of London.

Miller, D. H., and W. W. Savage. 1977. "Ethnic stereotypes and the frontier: A comparative study of Roman and American experience." In D. H. Miller and S. O. Steffen (eds.), The frontier: Comparative studies, 109-137. Norman, OK: University of Oklahoma Press.

Mommsen, T. 1885. Römische Geschichte. Vol. 5, Die Provinzen von Caesar bis Diocletian. Berlin: Weidmann.

Monson, A. 2012. From the Ptolemies to the Romans: Political and economic change in Egypt. Cambridge: Cambridge University Press.

Monson, A., and W. Scheidel, eds. 2015. Fiscal regimes and the political economy of premodern states. Cambridge: Cambridge University Press.

Morley, N. 2007a. "The early Roman Empire: Distribution.” In Scheidel, Morris, and Saller (2007), 570-591.

-. 2007b. Trade in classical antiquity. Cambridge: Cambridge University Press.

-. 2009. Antiquity and modernity. Malden, MA: Wiley-Blackwell.

Morris, I. 1994. "The Athenian economy 25 years after The Ancient Economy." Classical Philology 99, 351-366.

-. 1999. "Negotiated peripherality in Iron Age Greece: Accepting and resisting the East." In P. N. Kardulias (ed.), World-systems theory in practice: Leadership, production, and exchange, 6384. Lanham, MD: Rowman \& Littlefield. 
-. 2010. Why the West rules - For now: The patterns of history, and what they reveal about the future. New York, NY: Farrar, Straus and Giroux.

Morris, I., and J. G. Manning. 2005. “Introduction.” In J. G. Manning and I. Morris (eds.), The ancient economy: Evidence and models, 1-44. Stanford, CA: Stanford University Press.

Morris, I., R. Saller, and W. Scheidel. 2007. “Introduction.” In Scheidel, Morris, and Saller (2007), 1-12.

Motyl, A. J. 2001. Imperial ends: The decay, collapse, and revival of empires. New York, NY: Columbia University Press.

Murphy, T. 2004. Pliny the Elder's Natural History: The empire in the encyclopedia. Oxford: Oxford University Press.

Nafissi, M. 2005. Ancient Athens and modern ideology: Value, theory and evidence in historical sciences: Max Weber, Karl Polanyi and Moses Finley. London: Institute of Classical Studies, University of London.

Nappo, D. 2018. I porti romani nel Mar Rosso da Augusto al tardoantico. Naples: FedOA Press. North, D. C. 1981. Structure and change in economic history. New York, NY: W. W. Norton \& Co.

-. 1990. Institutions, institutional change and economic performance. Cambridge: Cambridge University Press.

Pitts, M., and M. J. Versluys, eds. 2015. Globalisation and the Roman world: World history, connectivity and material culture. Cambridge: Cambridge University Press.

Polanyi, K. 1944. The great transformation. New York, NY: Rinehart.

-. 1957a. "Aristotle discovers the economy." In Polanyi, Arensberg, and Pearson (1957), 64-96.

-. 1957b. "The economy as an instituted process." In Polanyi, Arensberg, and Pearson (1957), 243-269.

-. 1963. "Ports of trade in early societies." Journal of Economic History 23, 30-45.

-. 1977. The livelihood of man. New York, NY: Academic Press.

Polanyi, K., C. M. Arensberg, and H. R. Pearson. 1957. Trade and market in the early empires: Economies in history and theory. New York, NY: Free Press.

Purcell, N. 2017. "Mountain margins: Power, resources and environmental inequality in antiquity." P. Derron, and S. von Reden (eds.), Économie et inégalité: Ressources, échanges et pouvoir dans l'Antiquité classique: Huit exposés suivis de discussions: 22-26 août 2016, 75-105. Geneva: Fondation Hardt.

Raschke, M. G. 1978. “New studies in Roman commerce with the East.” In H. Temporini (ed.), Aufstieg und Niedergang der römischen Welt. Part 2. Vol. 9.2, 604-1378. Berlin: De Gruyter.

Rathbone, D. 2007. “Roman Egypt.” In Scheidel, Morris, and Saller (2007), 698-719.

Rathbone, D., and S. von Reden. 2015. “Mediterranean grain prices in classical antiquity." In R. J. van der Spek, B. van Leeuwen, and J. L. van Zanden (eds.), A history of market performance: From ancient Babylonia to the modern world, 149-235. London: Routledge.

Ray, H. P. 2003. The archaeology of seafaring in ancient South Asia. Cambridge: Cambridge University Press.

-. 2008. Colonial Archaeology in South Asia. The legacy of Mortimer Wheeler. Oxford: Oxford University Press.

Renfrew, C., and P. Bahn. 1991. Archaeology: Theories, methods and practice. London: Thames and Hudson.

Rice Holmes, T. R. 1928-1931. The architect of the Roman Empire. 2 vols. Oxford: Clarendon.

Roll, E. 1956. The History of economic thought. London: Faber and Faber.

Rostovtzeff, M. 1941. The social and economic history of the Hellenistic world. 2 vols. Oxford: Clarendon.

-. (1926) 1957. The social and economic history of the Roman Empire. 2nd ed. Oxford: Clarendon.

Saller, R. 2001. "Framing the debate over growth in the ancient economy." In Scheidel and von Reden (2001), 251-269. 
Sartre, M. 2000. "Syria and Arabia." In A. K. Bowman, P. D. R. Garnsey, and D. W. Rathbone (eds.), The Cambridge ancient history. 2nd ed. Vol. 11, 635-663. Cambridge: Cambridge University Press.

Scheidel, W. 2012. "Studying the state." In P. F. Bang and W. Scheidel (eds.), The Oxford handbook of the state, 5-60. Oxford: Oxford University Press.

Scheidel, W., and S. von Reden, eds. 2001. The Ancient Economy. Edinburgh: Edinburgh University Press.

Scheidel, W., I. Morris, and R. Saller, eds. 2007. The Cambridge economic history of the GrecoRoman world. Cambridge: Cambridge University Press.

Schneider, H. 1988. "Schottische Aufklärung und antike Gesellschaft." In P. Kneissl and V. Losemann (eds.), Alte Geschichte und Wissenschaftsgeschichte: Festschrift für Karl Christ, 431-464. Darmstadt: Wissenschaftliche Buchgesellschaft.

Schneider, P. 2019. "Erythrean pearls in the Roman world: Features and aspects of luxury consumption (late second century BCE-second century CE)." In M. A. Cobb (ed.), The Indian Ocean trade in antiquity: Political, cultural and economic impacts, 135-157. London: Routledge.

Seland, E. H. 2016. Ships of the desert and ships of the sea: Palmyra in the world trade of the first three centuries CE. Wiesbaden: Harrassowitz.

Shaw, B. 1990. "Bandit highlands and lowland peace: The mountains of Isauria-Cilicia." Journal of the Economic and Social History of the Orient 33, 199-270.

Sherrat, A., and S. Sherrat. 1993. "The growth of the Mediterranean economy in the early first millennium BC." World Archaeology 24, 361-378.

Sidebotham, S. E. 2011. Berenike and the ancient maritime spice route. Berkeley, CA: University of California Press.

Sidebotham, S. E., and J. Gates-Foster. 2019. The archaeological survey of the desert roads between Berenike and the Nile Valley: Expeditions by the University of Michigan and the University of Delaware to the Eastern Desert of Egypt, 1987-2015. Boston, MA: American Schools of Oriental Research.

Smith, A. (1776) 1961. An inquiry into the nature and causes of the wealth of nations. London: Methuen.

Speidel, M. A. 2016. "Fernhandel und Freundschaft zu Roms Amici an den Handelsrouten nach Südarabien und Indien." Orbis Terrarum 14, 155-193.

Syme, R. 1934. "The northern frontiers under Augustus.” In S. A. Cook, F. E. Adcock, and M. P. Charlesworth (eds.), The Cambridge ancient history. Vol. 10, 340-381. Cambridge: Cambridge University Press.

Thomas, R. I. 2012. "Port communities and the Erythraean Sea trade." British Museum Studies in Ancient Egypt and Sudan 18, 169-199.

Tomber, R. 2008. Indo-Roman trade: From pots to pepper. London: Duckworth.

Van der Spek, R. J. 2007. “The Hellenistic Near East.” In Scheidel, Morris, and Saller (2007), 409-433.

Versluys, M. J. 2014. "Understanding objects in motion: An archaeological dialogue on Romanization.” Archaeological Dialogues 21, 1-20.

von Domaszewski, A. 1914. Geschichte der römischen Kaiser. 2nd ed. 2 vols. Leipzig: Quelle \& Meyer.

-. 1967. Die Rangordnung des römischen Heeres. 2nd ed. by B. Dobson. Cologne: Böhlau.

von Richthofen, F. 1877-1912. China: Ergebnisse eigener Reisen und darauf gegründeter Studien. 5 vols. Berlin: Reimer.

Wagner-Hasel, B. 2004. “Le regard de Karl Bücher sur l'économie antique et le débat sur théorie économique et histoire." In H. Bruhns (ed.), L'histoire et l'économie politique en Allemagne autour de 1900, 159-183. Paris: Maison de Science de l'homme. 
Wallerstein, I. M. 1974. The modern world-system: Capitalist agriculture and the origins of the European world-economy in the sixteenth century. New York, NY: Academic Press.

-. 2004. World-systems analysis: An introduction. Durham, NC: Duke University Press.

Weber, M. 1897. “Agrarverhältnisse im Altertum.” In J. Conrad et al. (eds.), Handwörterbuch der Staatswissenschaften. Suppl. Vol. 2, 1-18. Jena: Fischer.

Weber, M. 1904. "Die 'Objektivität' sozialwissenschaftlicher und sozialpolitischer Erkenntnis.” Archiv für Sozialwissenschaften 19, 22-87.

Wells, B., ed. 1992. Agriculture in ancient Greece: Proceedings of the seventh international symposium at the Swedish Institute at Athens, 16-17 May 1990. Stockholm: Åström.

Wells, C. M. 1972. The German policy of Augustus: An examination of the archaeological evidence. Oxford: Clarendon.

-. 1991. "The problems of desert frontiers." In V. A. Maxfield and M. J. Dobson (eds.), Roman frontier studies 1989: Proceedings of the 15. International Congress of Roman Frontier Studies, 478-481. Exeter: University of Exeter Press.

Wells, P., ed. 2013. Rome beyond its frontiers: Imports, attitudes and practices. Portsmouth, RI: Journal of Roman Archaeology.

Wheeler, M. 1954. Rome beyond the imperial frontiers. London: Bell and Sons.

Wheeler, E. L. 1993. "Methodological limits and the mirage of Roman strategy: Part I \& II." Journal of Military History 57.1, 7-41 and 57.2, 215-240.

Whittaker, C. R. 1994. Frontiers of the Roman Empire: A social and economic history, Baltimore, MD: Johns Hopkins University Press.

-. 2004. Rome and its frontiers: The dynamics of empire. London: Routledge.

Wilson, A. 2015. "Red Sea trade and the state." In De Romanis and Maiuro (2015), 13-32.

Wilson, A., and A. K. Bowman. 2018. "Introduction: Trade, commerce and the state." In Wilson and Bowman (2018), 1-26.

Woolf, G. 1990. "World systems analysis and the Roman Empire." Journal of Roman Archaeology 3, 44-58.

-. 1992. "Imperialism, empire and the integration of the Roman economy." World Archaeology 23, 283-293.

-. 1993. “Roman peace." In J. Rich and G. Shipley (eds.), War and society in the Roman world, 171-194. London: Routledge.

-. 1998. Becoming Roman: The origins of provincial civilization in Gaul. Cambridge: Cambridge University Press.

-. 2014. "Romanization 2.0 and its alternatives." Archaeological Dialogues 21, 45-50.

Young, G. K. 2001. Rome's eastern trade: International commerce and imperial policy, $31 B C-A D$ 305. eLondon: Routledge. 
